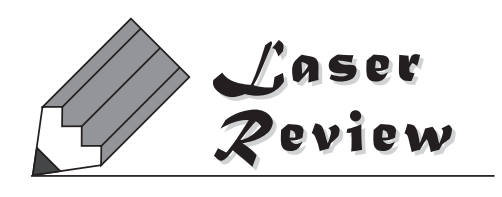

\author{
テラヘルツ量子カスケードレーザーの進展 \\ 平山 秀樹 ${ }^{1,2}$, 寺嶋 亘 $^{1,2}$, 林 宗澤 ${ }^{1}$ \\ 1理化学研究所 ·光量子工学研究領域 ( T980-0845 宮城県仙台市青葉区荒巻字青葉519-1399) \\ ${ }^{2}$ 理化学研究所 ( $3351-0198$ 埼玉県和光市広沢2-1)
}

\title{
Recent Progress of Terahertz Quantum Cascade Lasers
}

\author{
Hideki HIRAYAMA ${ }^{1,2}$, Wataru TERASHIMA ${ }^{1,2}$, and Tsung-Tse LIN ${ }^{1}$ \\ ${ }^{1}$ RIKEN Center for Advanced Photonics (RAP), 519-1399 Aoba Aramaki, Sendai, Miyagi 980-0845 \\ ${ }^{2}$ RIKEN, 2-1 Hirosawa, Wako, Saitama 351-0198
}

(Received May 2, 2016)

\begin{abstract}
Terahertz quantum cascade laser (THz-QCL) is a compact, high output power, narrow linewidth and low cost terahertz laser, and is very attractive for a lot of applications as a practical use terahertz light source. In this report, we demonstrate our recent research activities on the development of high performance THz-QCLs, i.e., realization of higher temperature operation of THz-QCL using an indirect injection scheme QC design, high output power operation of THz-QCLs at $77 \mathrm{~K}$ liquid nitrogen temperature and development of unexplored frequency THz-QCLs using nitride semiconductors. Through these studies, we also discuss on the future prospects of THz-QCLs.
\end{abstract}

Key Words: Terahertz, Quantum-cascade laser, LO-phonon scattering, MBE, Nitride semiconductors

1.はじめに

テラヘルツ量子カスケードレーザー (THz quantum-cascade laser: QCL) は小型, 高出力, 狭線幅, 安価, 連続動 作可能なテラヘルッレーザー光源として今後の実用化が 期待されている。既にテラヘルッパラメトリック発振器 などを用いて実用化しているテラヘルツ分析装置, 各種 透視・非破壊検査用の光源の置き換えとして, また, 携 帯用の検査用レーザー光源としての応用が期待されてい る.テラヘルツ光源は, 郵便物や税関検査などのセキュ リティ検査, 食品などの異物混入検査, ICチップ検査な ど電子産業への応用, 火傷診断, 癌細胞の識別, 虫歯の 検査など医療応用, 農作物検査, 構造物内部の検査な ど，非常に広範囲の応用が考えられている。

Fig. 1にTHz-QCLの外観写真, 構造模式図, 活性層の バンド図の例を示す。THz-QCLは，半導体超格子のサ ブバンド間遷移発光を用いたレーザーである，発光層の 1ユニットは4量子井戸などで構成されており，これを 200 ユニット程度積層し, トータルの厚さが $10 \mu \mathrm{m}$ 程度 の活性領域とする。超格子活性層に電界を印可し, 量子 準位の階段を人工的に作り，電子を滝の様に流すことに よって, 一つの電子が何回も遷移発光を繰り返す。キャ リアリサイクリングによる高出力動作が特徴である。テ ラヘルツ周波数帯では, 半導体のドーピング層は光吸収 が大きくて導波路として使えないため, 活性領域の一方 または両方に金属を設けた表面プラズモン導波路が用い
られる。

Fig. 2に，現在までに報告されているTHz-QCLの発振 周波数と動作温度の関係を示す。THz-QCLは，2002年 に初めて実現され ${ }^{1)}$ ，現在までに報告されている発振周 波数範囲は1.2 5.2 $\mathrm{THz}^{2,3)}$, 最高動作温度は約 $200 \mathrm{~K}$ $(3.2 \mathrm{THz})^{4)}$ である。また，パルス動作で1 W程度の高出 力動作も報告されている5 . THz-QCLの実用化のために は, 室温発振と周波数の拡大が重要な課題である。我々 は, GaAsおよび $\mathrm{GaN}$ 系半導体を用いたTHz-QCLの開発 に2005年から取り組んでおり，これまでに分子線エピ夕 キシー $(\mathrm{MBE})$ 結晶成長装置を3台導入し THz-QCLの開発 を行ってきた ${ }^{6,7)}$. Fig. 2 に本研究で最近までに達成した 実験結果を書き加えた。AlGaAs系QCLの研究では, 2011年に3.7 THzで143 K ${ }^{8)}$ ，2012年に $3.8 \mathrm{THz}$ で $150 \mathrm{~K}^{9)}$ の 発振に相次いで成功し, さらに，2013年になって，低周 波領域の世界最高レベルの動作温度における発振 $(160 \mathrm{~K}$, $1.9 \mathrm{THz})^{10)}$ に成功した。 また，未開拓波長 $(5 \sim 12 \mathrm{THz})$ のQCLを実現するために, 窒化物半導体QCLの開発を早 くから行っており ${ }^{11-13)}$, 最近, 世界初のレーザー発振を 実現した。 Fig. 2に同様に, 我々が最近行っているTHzQCL高性能化へのアプローチを示した。我々は最近, 「間接注入機構を利用した低周波数QCLの動作高温化」 と,「窒化物半導体を用いた未開拓波長QCLの開発」を 行っている。本稿では, 我々が取り組んでいる $\mathrm{THz}-$ QCL高性能化へのアプローチと今後の展望について紹介 する. 
(a)

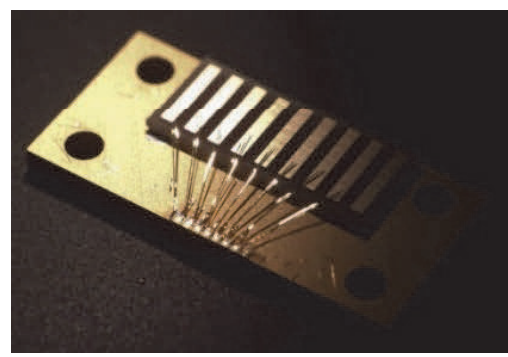

(b)

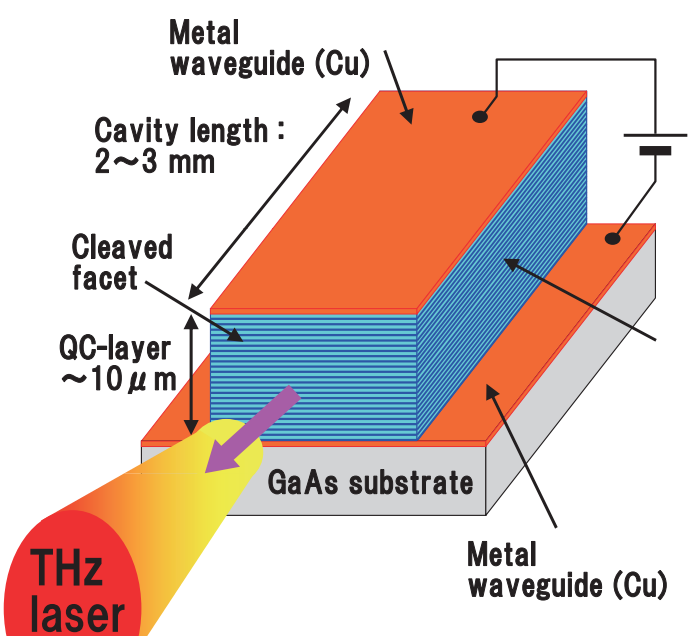

(c)
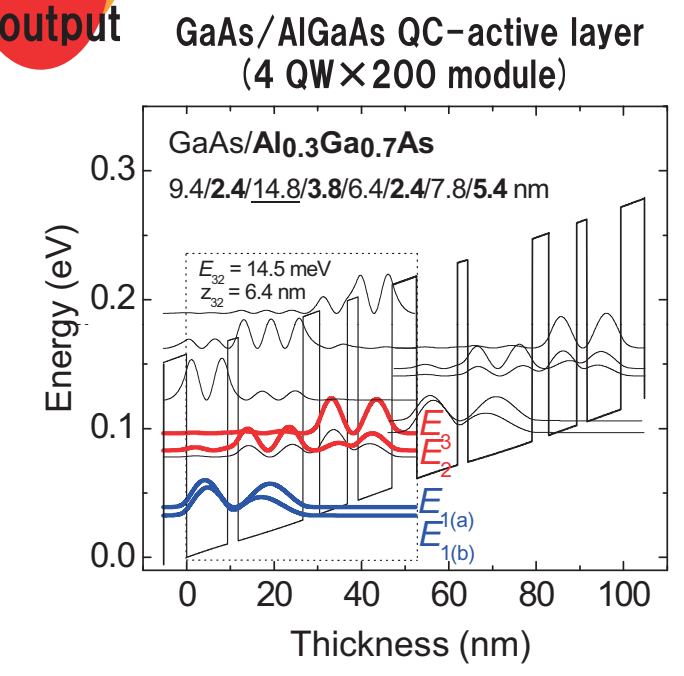

Fig. 1 (a) Digital camera image of THz-QCL sample mounted on $\mathrm{CuW}$ heat sink, (b) schematic structure and (c) example of conduction band profile and wavefunctions of $\mathrm{QC}$ active region of $\mathrm{GaAs} /$ AlGaAs THz-QCL.

\section{2. 間接注入機構を用いたTHz-QCLの動作温度の向上}

本研究ではTHz-QCLの動作温度の向上を図るために, 間接注入機構 ${ }^{13)}$ の導入を行っている. THz-QCLの低周波 数側 $(<2 \mathrm{THz})$ の動作は, レーザー発振の準位間隔が4〜 $8 \mathrm{meV}$ と狭くなるにしたがって, 電子が発振上下準位の 両方に同時に注入され，反転分布が制限される。低周波 数QCLで高温動作を得るためには, 発振の上位準位に選 択的に電子を注入することが重要である。

Fig. 3に, 従来までに用いていた共鳴トンネル注入機 構 $(3$ 準位系) と今回用いた間接注入機構 $(4$ 準位系)の量子

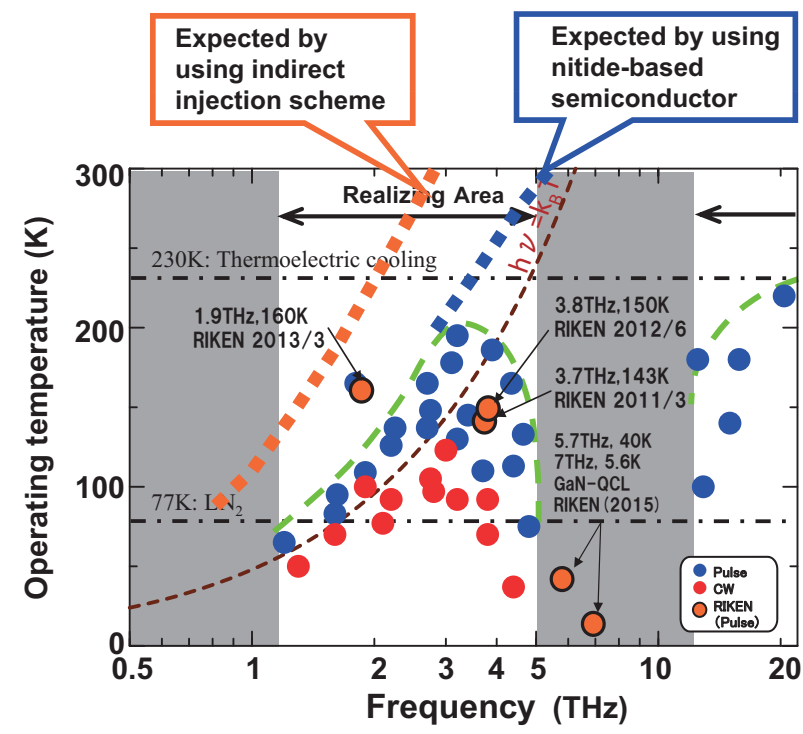

Fig. 2 Current status of operating temperature and lasing frequency of THz-QCL and our approaches for realizing next generation high-performance $\mathrm{THz}-$ QCLs.

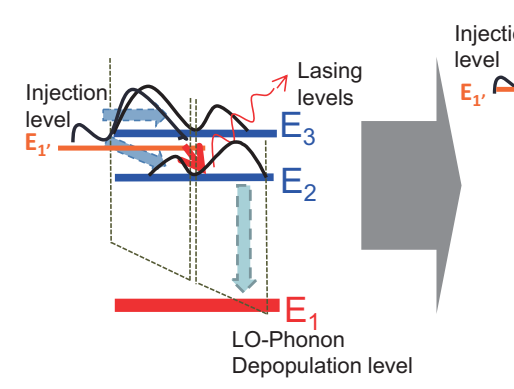

(a)

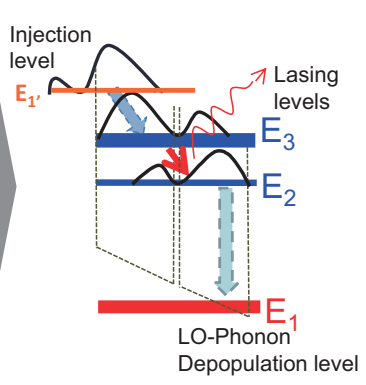

(b)
Fig. 3 Schematic view of quantum well design used for (a) resonant tunneling (RT) injection scheme (three-level system) and (b) indirect injection scheme (four-level system).

構造の特徴を示す。3準位機構は，LOフォノン散乱によ り発振下位準位の電子を高速に抜き取り, 反転分布をア シストする機構である。しかし，注入に関しては通常の 共鳴卜ンネル注入を用いて㧍り，発振エネルギー間隔が 小さくなると, 発振上位準位と下位準位に同時に電子が 注入され，反転分布を阻害する。一方，間接注入機構を 取り入れた構造では，一段高い準位からLOフォノン散 乱を用いて発振上位準位のみに選択的に電子注入を行う ことが可能となり,この機構を用いれば, 低周波数 THz-QCLの高温動作が可能となる ${ }^{13,14)}$.

Fig. 2に，間接注入を用いた場合に期待されるQCLの 動作範囲を書き加えた，間接注入の導入は，特に低周波 数QCLの動作温度の向上に効果が期待され，熱的な制限 ライン $\left(k_{\mathrm{B}} T\right.$ ライン $)$ 以上の動作温度範囲を大きく広げる ことが期待される. Fig. 2のオレンジ点線ラインで示し た動作温度は，厳密な計算によるものではなく，注入準 位の電子のエネルギー分布を考慮して発振上位準位への 選択的電子注入が行われる様子から大まかに予測したも 
のである. 我々の結果も含め最近報告されている実験結 果も考慮しているが，200 K以上の高温動作に関しては 希望的な見方も含まれている。間接注入機構を用いた先 行研究 (2.4 THzにおける152.5 K 発振 ${ }^{15)}, 2.67 \mathrm{THz}$ におけ

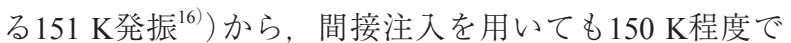
平行線になるとの予測もある。一方，1〜2 THz低周波 領域で注入機構による制限要因がなくなればもっと高温 化が期待されるという見方もある。我々は，温度上昇に 伴う注入準位の電子エネルギー広がりによって発振上位 準位への注入選択性が変化すると考え, $k_{\mathrm{B}} T$ ラインに 沿って動作温度が上昇すると考えている。

間接注入を用いたTHz-QCLの結果は再現実験の報告 が少なく傾向がつかみにくい，我々の結果についても， 今後, 構造最適化による動作温度の高温化の可能性が十 分考えられる。間接注入THz-QCLに関しては, 今後, 詳細な解析による効果の予測を行う必要がある。

Fig. 4に作製した両面金属導波路THz-QCLの電子顕微 鏡 $(\mathrm{SEM})$ 写真, 及び, 通常作製している3準位系量子構

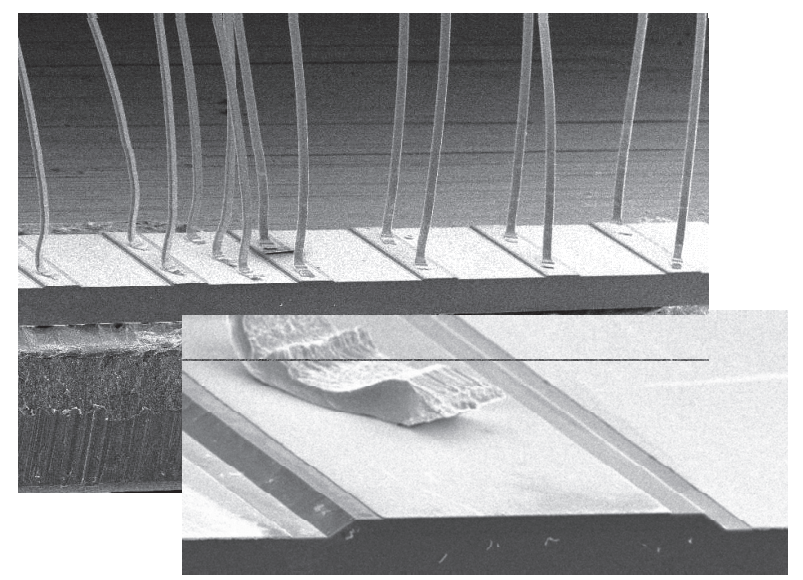

(a)

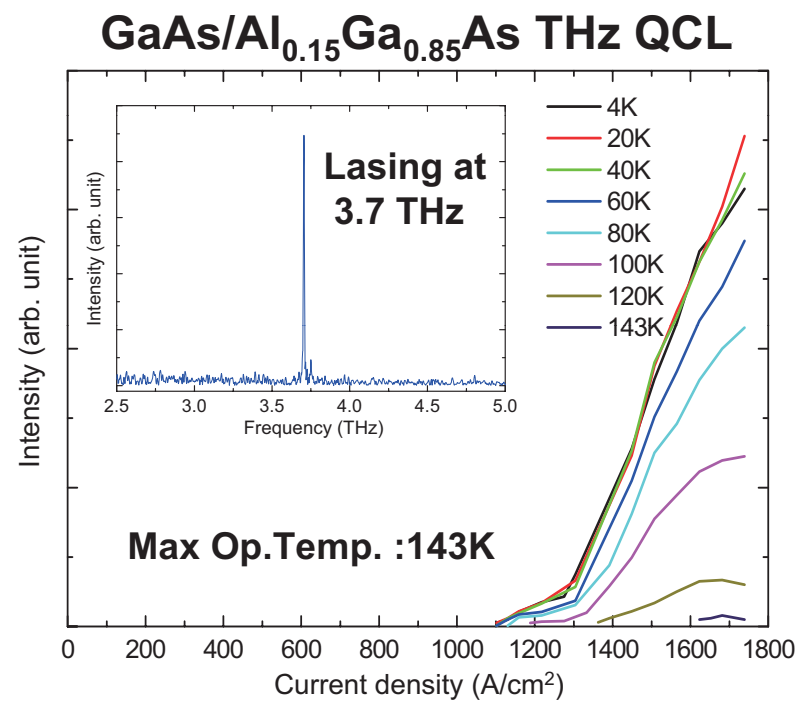

(b)

Fig. 4 (a) Scanning electron microscopy (SEM) image and (b) current-light output $(I-L)$ characteristics of fabricated 3-level design GaAs/AlGaAs THz-QCL with double metal waveguide (DMW) structure.
造を用いたGaAs/AlGaAs THz-QCLのレーザー発振スペ クトルおよび電流-電圧 $(\mathrm{I}-\mathrm{V})$, 電流-光出力 $(\mathrm{I}-\mathrm{L})$ 特性を 示す. $\mathrm{QCL}$ 構造は, $\mathrm{MBE}$ によって半絶縁性の $\mathrm{GaAs}(100)$ 基板上に成長した。初めに $\mathrm{Al}_{0.6} \mathrm{Ga}_{0.4} \mathrm{As}$ エッチングストッ プ層を $250 \mathrm{~nm}$ 成長させ, さらに $\mathrm{Al}_{0.18} \mathrm{Ga}_{0.82} \mathrm{As} / \mathrm{GaAs}$ 活性層 を，4量子井戸を 1 周期とし 185 周期成長させた。一番厚 い注入層には $2 \times 10^{16} \mathrm{~cm}^{-3}$ の Siドーピングを行った。活 性層は100 nm厚のn-GaAs コンタクト層で挟み込んだ構 造とした，導波路層の伝搬損失を低くするために，両面 金属(DMW)プラズモン導波路を形成した。

DMW構造は，メタルボンディングと基板リフトオフ プロセスなどを用いて形成した。高い熱伝導と低い導波 路損失が得られる銅 $(\mathrm{Cu})$ をDMWのメタル層に用いた。 測定はTHz FT-IRと冷却したSiボロメーターを用い，パ ルス電流注入に拈いて行った. Fig. 4(b)に示す様に, 我々は通常レファレンスサンプルとして3.5〜3.8 THzの 3 準位系QCLを作製しており, 最高動作温度140 K程度を 得ている.

Fig. 5に，今回作製した間接注入型(4準位系) GaAs/AlGaAs THz-QCLのレーザー発振スペクトルおよびI- $V, I-L$ 特性を示す。1.89 THzにおいて最高動作温度160 Kでの 発振に成功した。 また得られた発振は，周波数が印加バ イアス電圧によって切り替わらない安定動作であった。 今回得られた動作は， $k_{\mathrm{B}} T$ ラインの1.8倍という高い動作 温度であり，2 THz以下の低周波数QCLにおける最高動 作温度を実現した。THz-QCLの高温動作の実現におい て新しい領域の結果であると考えられる。これまで3準 位系の共鳴トンネル注入機構でこのような結果は得られ なかったので, 間接注入機構は低周波域QCLの高温動作 に適した構造であるといえる。

4準位系の間接注入機構では低バイアス印加時に3準位 系の構造になり，意図しない高周波域でレーザー発振が 起こりやすいという特徵がある. MITのグループは2010年 に4準位系の間接注入型THz-QCLで1.8 THzにおいて163 K の発振を報告したが(4)，低バイアス印加時には4 THz付 近で発振してしまい，2周波数を行き来する不安定動作

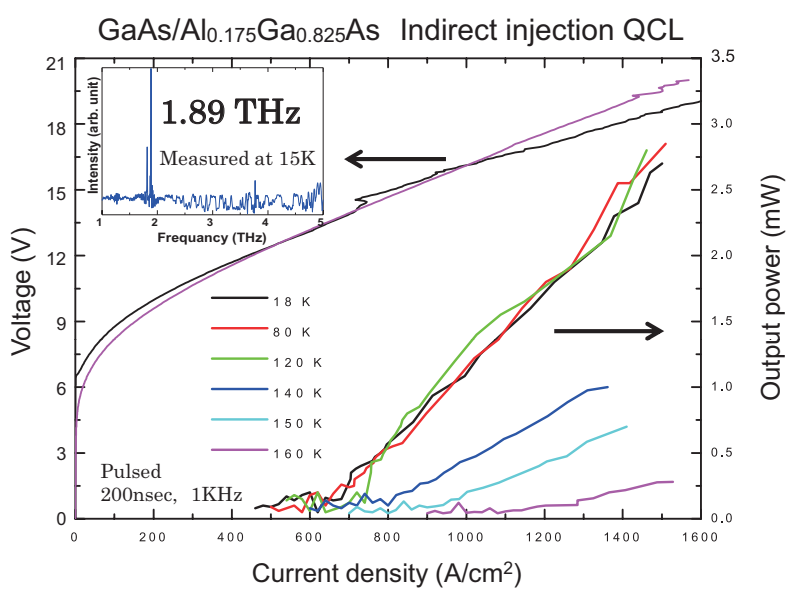

Fig. 5 Current-voltage $(I-V)$ and $I-L$ characteristics of indirect injection scheme (4-level design) GaAs/AlGaAs THz-QCL with DMW structure. 
となった，本研究では，低バイアス印加時の波動関数の 重なり積分が小さくなるようにディチューニングし，ま た，注入準位と発振上位準位のエネルギー差を $\mathrm{GaAs} の$ LOフォノンエネルギーである $36 \mathrm{meV} に$ 近い值にすること で，意図しない高周波でのレーザー発振を阻止している.

\section{3. 実用型高出力THz-QCL開発の現状}

THz-QCLの室温発振までにはまだ大きなバリアがあ り実現が難しい，本研究では，液体窒素デュワー，もし くは小型スターリング冷凍機に搭載して高出力動作する 実用型THz-QCLの作製を試みている。スターリング冷 凍機は液体窒素の供給なしに長時間安定動作ができる点 で優れている。冷凍機搭載を目的として, 70〜 $100 \mathrm{~K}$ 程 度の温度で高出力が得られるTHz-QCLの開発を行って いる.

前節までに述べたTHz-QCLの高温動作を追求するた めには，光閉込め係数が $99 \%$ 以上と大きくとれるダブル メタル導波路 (DMW) 構造が優れている. 一方, DMW 構造では共振器端面における反射が大きくなるため, 高 出力動作が難しいという問題がある。 それに対して, 片 面金属導波路構造を用いた場合, 光閉込め係数は $30 \%$ 程 度と低くネットゲインが低くなるため, $120 \mathrm{~K}$ 以上の温 度での動作は難しい，一方，DMWの時の様な共振器端 面での高反射効果は起こらないため，低温ではむしろ高 出力が得られる。

最近, 片面金属導波路型GaAs系THz-QCLでリッジ幅 を大きくし，また共振器を片面高反射 (HR) コートする ことによって, 温度 $10 \mathrm{~K} て 1 \mathrm{~W}$ 超える高出力動作が報

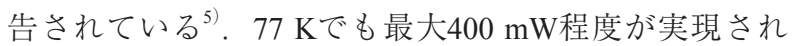
ており ${ }^{17)}$ (いずれもパルス動作ピーク出力), 冷凍機搭載 型THz-QCLに扔いて $100 \mathrm{~mW}$ クスの高出力光源の実現 が期待されるようになった，我々は，高出力動作を目指 した3準位系THz-QCL ${ }^{18)}$ を作製した。

Fig. 6に，作製した片面金属導波路型GaAs/AlGaAs THz-QCLのレーザー発振スペクトルおよびI-V, I-L特性 を示す. $4.2 \mathrm{THz}$ 付近で発振し, 温度 $10 \mathrm{~K} に$ 扔いてパル

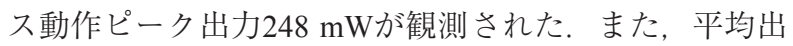

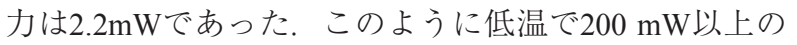
高出力が得られることが確認できた。片面金属導波路型 のQCLでは, 光閉込め倸数が小さいため, $80 \mathrm{~K}$ 以上の温 度では急激に出力が低下し最高動作温度は100〜120 K と なる ${ }^{16)}$ ，本サンプルでは $60 \mathrm{~K}$ 程度から急激に出力低下し $80 \mathrm{~K} て ゙ は 2 \mathrm{~mW}$ 程度まで出力が減少してしまっており， 今後の改善が必要である。レーザー発振準位間の斜め遷 移の割合を調節することにより, より高温動作に適応し たQCLが実現できると考えられ，現在検討中である．

Fig. 7に，本研究で作製した液体窒素デュワー一体型 THz-QCLの外観及び内部機構を示す。デュワー内部に 角度と位置の調節機能を有する放物面鏡が取り付けられ ており，レーザー光は出射空から平行光として取り出す ことができる。 また，QCLからの光出力を前方にフォー カスするためにQCLチップにSiレンズを取り付けてい

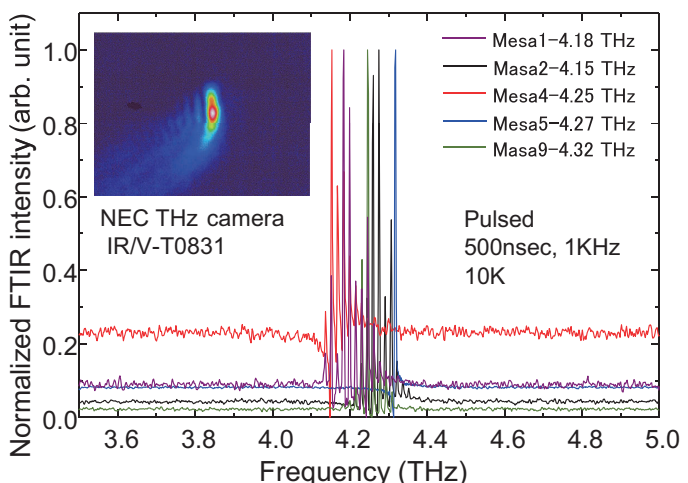

(a)

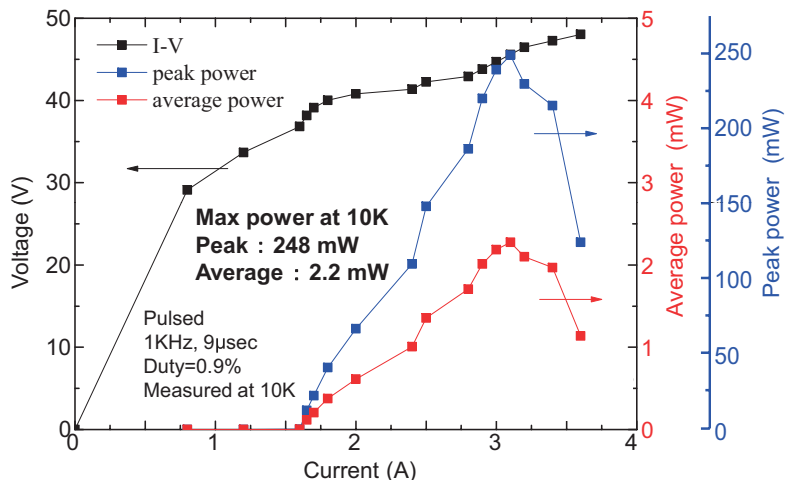

(b)

Fig. 6 (a) Lasing spectra and $\mathrm{THz}$ camera image and (b) $I-V$ and $I-L$ characteristics of 3-level design GaAs/ AlGaAs THz-QCL with single metal plasmon waveguide (SP) structure.

る. QCLチップは8メサを1ユニットとしてCuWヒート シンクに張り付けている.8メサのうち高出力が得られ るメサを出力用として用いている.

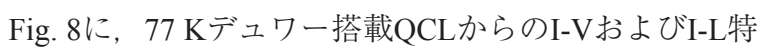
性を示す。QCL構造としては, これまで用いてきた3準 位系GaAs/AlGaAs系QCLで両面金属導波路構造を用い た. Fig. 8のサンプルでは, ピーク出力 $2.5 \mathrm{~mW}$, 平均出 力は $2.5 \mu \mathrm{W}$ が得られている. その後, 電流のパルス幅と 繰り返し周波数を変化させることにより, 最高ピーク出 力 $3.1 \mathrm{~mW}$, 最高平均出力 $6.2 \mu \mathrm{W}$ 観測された.

冷凍機搭載型QCLの高出力化は本研究でまだ開発途上 であるが，今後は，片面金属導波路型QCLに打ける発振 準位間遷移の制御と注入層のドーピング濃度の最適化な どを行うことで出力は大幅に向上すると考えられ，実用 型THz-QCLの実現を可能にしたいと考えている.

\section{4. 窒化物半導体を用いた未踏波長THz-QCLの開発}

5-12 THzのQCLは未だ実現されておらず,これらの未 開拓波長QCLの実現は大変重要な課題である。本研究で は, 窒化物半導体の特異な物性パラメー夕を用いて, QCLの動作周波数領域を飛躍的に広げることを検討して いる. 窒化物半導体の電子LOフォノン散乱エネルギー は90 meV程度でGaAsなどに比べ3倍程度大きく，また， 伝導帯のバンド不連続值も最大で $1.8 \mathrm{eV}(\mathrm{GaN} / \mathrm{AlN}$ の場 

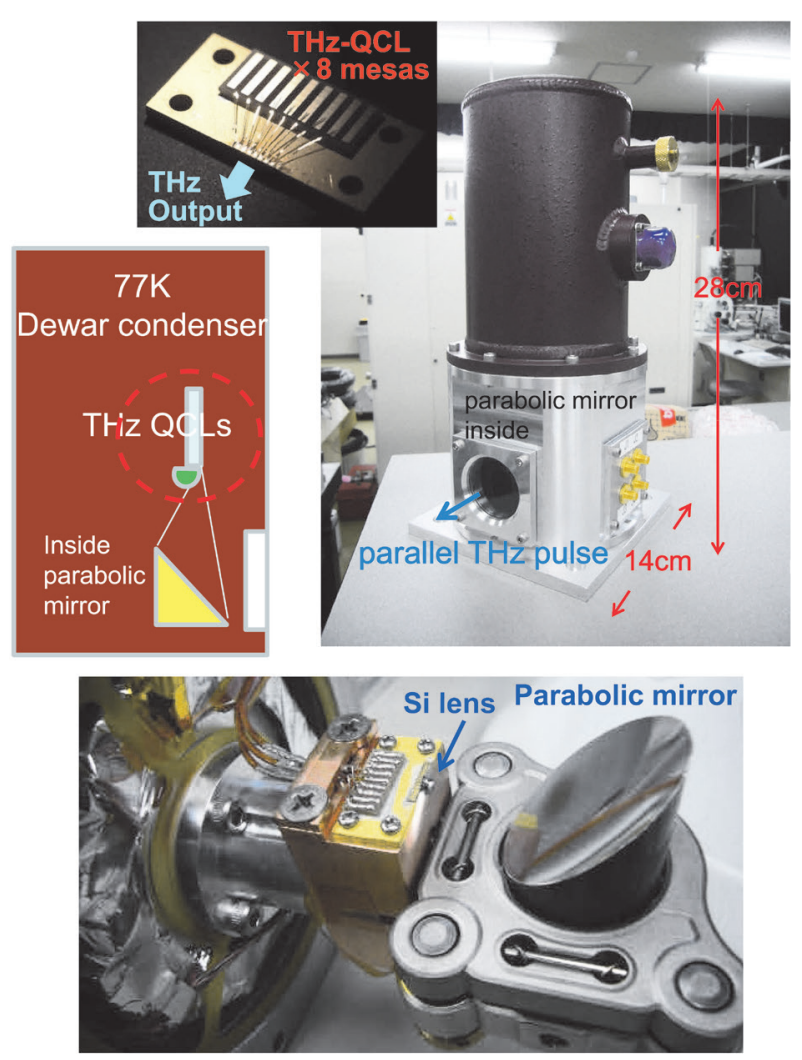

Fig. 7 Schematic image and pictures of liquid nitrogen $77 \mathrm{~K}$ dewar type THz-QCL light sours. THz-QCL mesas mounted on heat sink with Si lens and parabolic mirror are located inside the vacuum chamber.

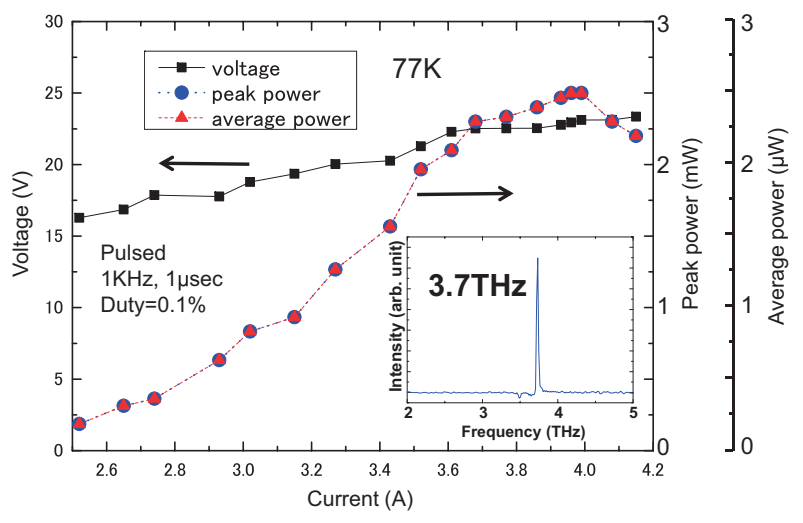

Fig. 8 Lasing spectra, I-V and I-L characteristics of a 3-level design GaAs/AlGaAs THz-QCL with DMW structure measured at $77 \mathrm{~K}$ using liquid nitrogen dewar.

合) と大きく, $\mathrm{GaAs}$ 系(最大值：0.6 eV (InGaAs/AlGaAs) ) に比べ約3倍大きい. Fig. 9に，これまでのQCLの実現波 長領域と, GaN系半導体の導入により実現が期待される 周波数領域を示す. GaAsのLOフォノン散乱吸収の影響 でこれまで発振が不可能だった領域(5-12 THz領域) は, $\mathrm{GaN}$ 系半導体を用いることにより可能になり, THz-QCL の周波数帯を3〜20 THzに拡張することが期待できる. また，GaAs及びInP基板を用いた中赤外領域のQCLの波 長は3〜20 $\mu \mathrm{m}$ に限られているが, $\mathrm{GaN}$ 系半導体を用いれ ば伝導帯のバンド不連続が大きいため, さらに短波長領
域の1〜8 $\mu \mathrm{m}$ 帯のQCLの実現が期待される。つまり, $\mathrm{GaN}$ 系半導体を用いることにより, 従来半導体で不可能 だったちょうど間の領域が実現され，広大な波長領域を カバーすることができる、

Fig. 2に同様にGaN系半導体を用いたTHz-QCLの動作 温度の予測を青色の点線で示した。これについても厳密 な解析に基くものではなく，希望的見方を含むものであ る. LOフォノン吸収の周波数帯が GaAs系半導体よりシ フトするため $20 \mathrm{THz}$ 以下の周波数での動作が期待され る. また今後, GaN系QCLの量子構造, 導波路構造の作 製技術が確立すれば， $k_{\mathrm{B}} T$ ライン付近までの動作温度が 可能であると考えられる。

我々は, 未開拓周波数QCLの実現を目指 L GaN/ AlGaN超格子構造を用いたQCLの作製を行っだ11-13).

Fig. 10に作製したGaN/AlGaN系THz-QCLの構造模式図 と, GaN系QCL実現のために導入した「純粋3準位系」量 子構造の設計について示す.

サファイア基板上に，まず有機金属気相成長 (MOCVD) 法を用いて高品質AlN/AlGaNバッファー層を製膜 し, その後MBE法を用いて $\mathrm{n}+\mathrm{GaN}$ プラズモン導波路層, $\mathrm{GaN} / \mathrm{AlGaN}$ 量子カスケード活性層を製膜した。サファ イア基板上の高品質AlNバッファーは, 本研究で並行し て行っている「深紫外LED」研究において開発したもの で, 貫通転位の低減により深紫外 $270 \mathrm{~nm}$ 波長帯のAlGaN 量子井戸において $60 \%$ 以上の内部量子効率を実現してい る、QCLで用いるバンド内遷移発光においても高効率発 光が可能であると考えられる。サンプルは, ドライエッ チングによりリッジ加工を施し，蒸着により片面金属プ ラズモン導波路層構造を形成した。

2量子井戸3準位系QCL構造に関しては先行して，A. Wackerら ${ }^{19)}\left(\mathrm{GaAs}\right.$ 系QCL), ならびに安田氏ら ${ }^{20,21)}(\mathrm{GaN}$ 系QCL)によって提案されている。我々は当初, GaAs系 THz-QCLで用いられているのと同様な4量子井戸型を用 いて GaN/AlGaN系QCLを作製したが発振動作には至ら なかった，C軸方向に成長された $\mathrm{GaN}$ 系半導体では，ピ エゾ電界・自然分極による分極が超格子に生じるため, 内部電界を考慮した設計を行う必要がある。特に, 大き な内部電界に起因し量子準位が縮退しにくいため, 縮退 が解かれた準位間でダイポールモーメントが発生し, 予 期しない準位から発光することが問題となる。本研究で は，そのような実験失敗の経緯から，我々は「純粋3準位 系」量子構造を導入した。無䭾な発光準位を排除して設 計通りの順位からの発光を得ることにより, GaN系QCL の初めてのレーザー発振を成功した。

本構造は, 間接注入機構も同時に取り入れた構造と なっている。 また, $\mathrm{GaN}$ 系半導体では, 電子-LOフォノ ン相互作用がGaAsなどに比べて大きく，量子準位の工 ネルギー広がりが問題となり, その結果, 光利得が減少 することが指摘されている位。そそれを防ぐために，発振 準位間の対角遷移の割合を大きく設計している 21 .

Fig. 11に，作製したGaN/AlGaN系量子カスケード活性 層のX線回折ロッキングカーブと断面透過電子顕微鏡 (TEM) 像の例を示す．X線回折のサテライトピークを観 


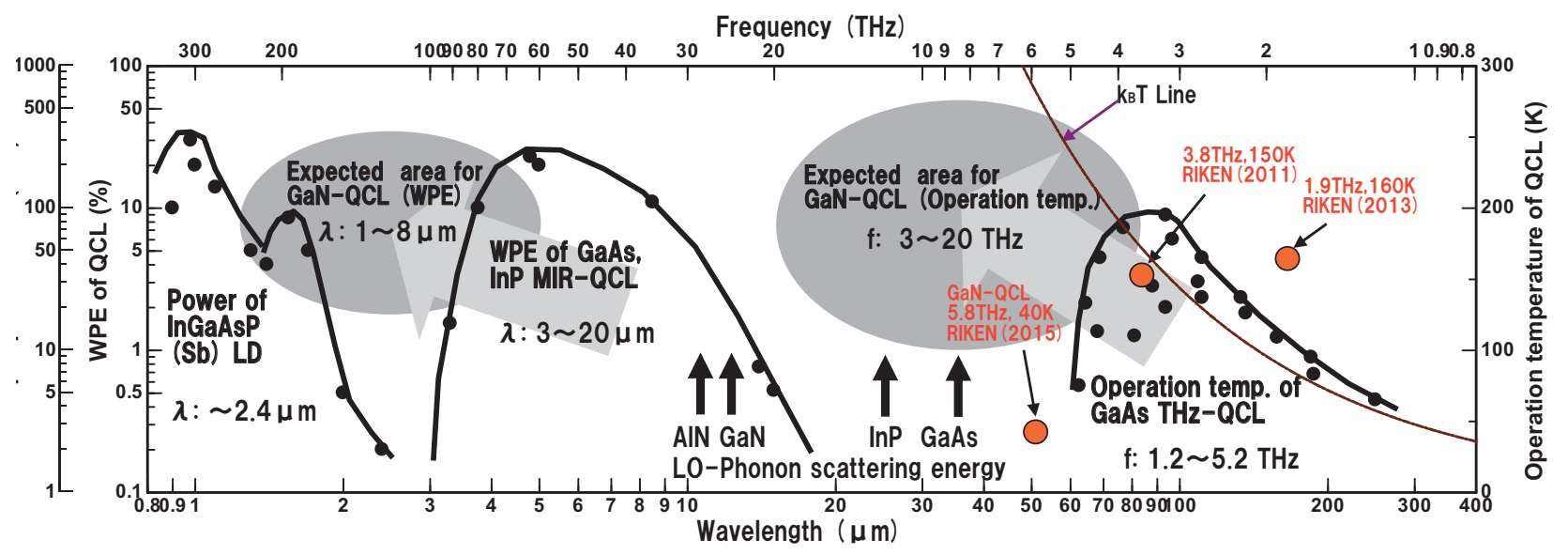

Fig. 9 Operating frequency range of GaAs and InP-based THz and mid-infrared (MIR)-QCLs and IR-laser diodes (LDs), and expected frequency range which will be developed by nitride semiconductor QCLs.

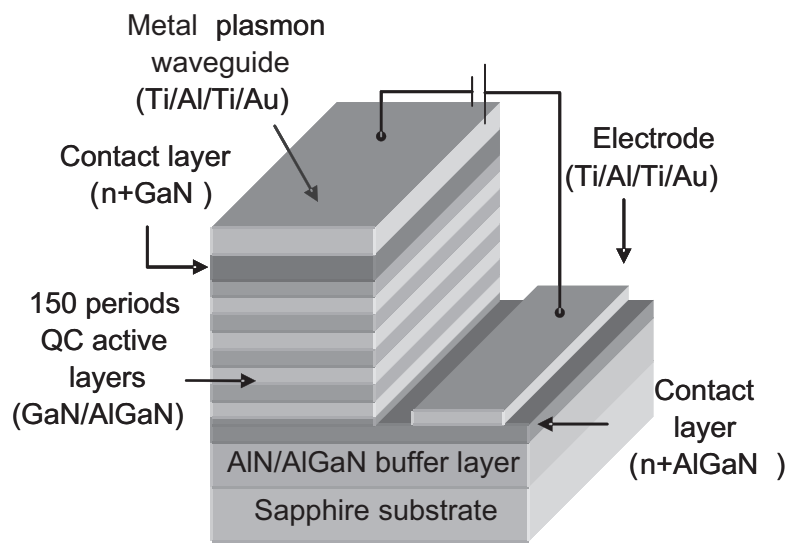

(a)

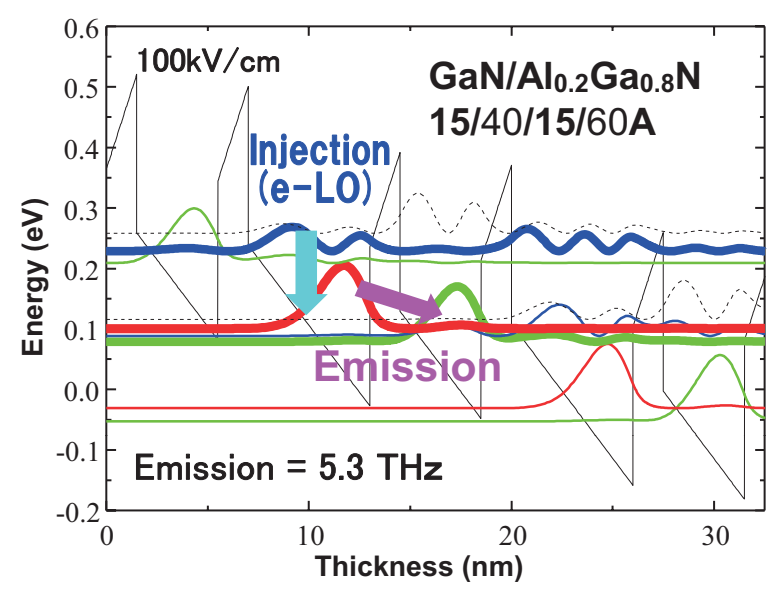

(b)

Fig. 10 (a) Schematic structure and (b) conduction-band diagram and wavefunctions of "Pure three-level" design GaN/AlGaN THz-QCL fabricated on AlN/ sapphire substrate.

測することにより，膜厚の絶対精度1\%程度を実現して いる。 また断面TEM像に見られるように，原子1層の急 峻さで多重超格子構造が形成されている。研究開始当 初, AlGaN系MBE結晶成長に扔いてQCLで必要となる 数百周期に及ぶ多重超格子の形成が難しく, 通常の成長

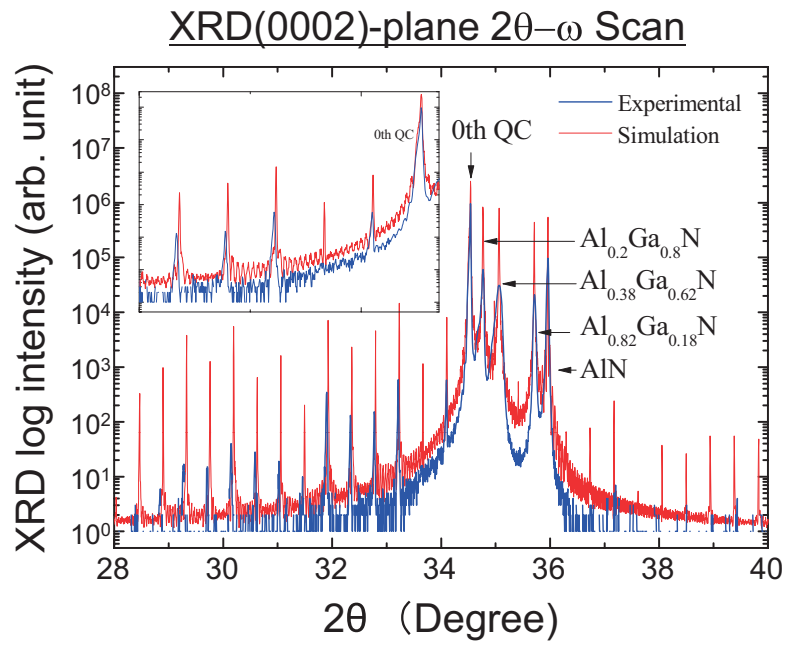

(a)

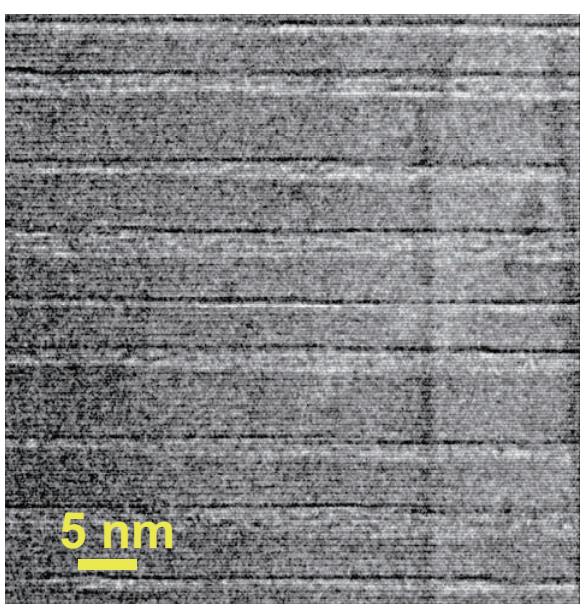

(b)

Fig. 11 (a) X-ray diffraction (XRD) (0002)-plane 2 $\theta-\omega$ scans and the simulation curve and (b) cross-sectional transmission electron microscopy (TEM) image taken for GaN/AlGaN QC structures.

では不可能であった，本研究では，独自に考案した「過 渡的アニールドロップレット除去法(DETA法)」を用い, 原子層平坦な高品質 $\mathrm{AlGaN} / \mathrm{GaN}$ 多重超格子の形成に成 


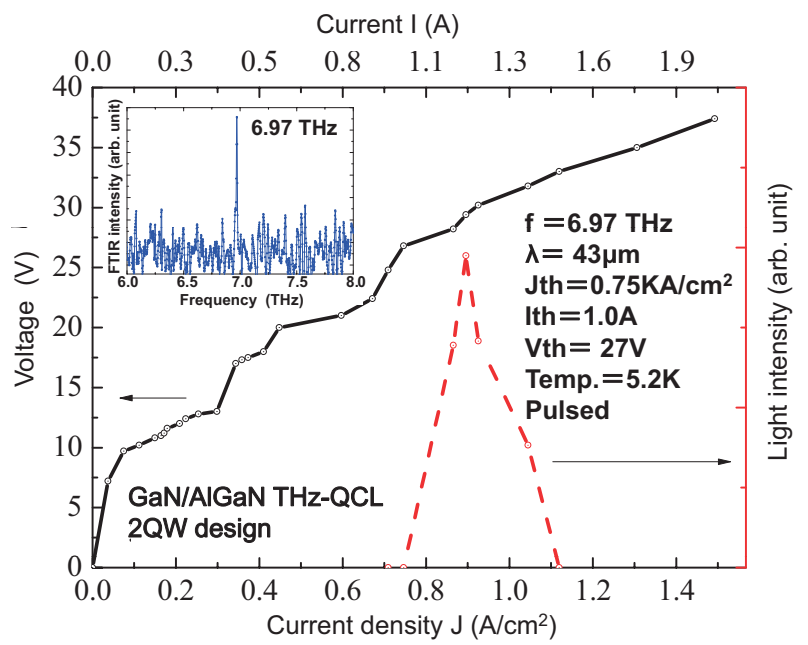

Fig. 12 Lasing spectrum and I-V and I-L characteristics obtained from a GaN/AlGaN THz-QCL fabricated on AlN/sapphire template measured at $5.2 \mathrm{~K}$.

功している11-13)。 また, 本研究では最近GaN系QCL層を MOCVDを用いて作製している。

$\mathrm{GaN} / \mathrm{AlGaN}$ THz-QCLにパルス電流注入を行い, 世界 初の窒化物QCLの発振を観測した。Fig. 12にGaN/AlGaN THz-QCLのレーザー発振スペクトルおよび電流-電圧, 光出力特性を示す。本サンプルのQC構造はMOCVDを 用いて作製した。これまでの未踏周波数である7 THzで レーザー発振が得られた。レーザー発振は注入電流が $1.1 \sim 1.5 \mathrm{~A}$ 範囲で得られ, 闇值電流密度は $0.75 \mathrm{kA} / \mathrm{cm}^{2}$, 閾值電圧は27 Vであった。本研究ではMBE法で作製し たサンプルも含め5.4〜 7 THzの領域でGaN系QCLの発振 動作を確認している。いずれもGaAs系では実現しな かった周波数領域であり GaN系半導体に特徵的な結果で ある. 現段階の構造では活性層厚が薄く光閉じ込め係数 が小さいため, 十分なレーザー発振特性が得られないと 考えられる。今後は構造を改善することにより, より広 範囲な周波数でのレーザー発振と高温動作が可能になる と考えられる。

\section{5. まとめ}

THz-QCLの高温, 高出力動作と周波数の拡大に関す る取り組みに関して紹介した。間接注入機構の導入によ
り低周波数QCLにおいて熱的制限ライン $\left(k_{\mathrm{B}} T\right.$ ライン)を 1.8 倍上回る温度でのレーザー発振を実現し, 今後の動 作温度の向上に向けて希望の持てる結果が得られた。 た GaN系QCLの初めての発振動作を達成し，未開拓周波 数である5.4〜7 THzのレーザー発振を実現した。今後こ れらの研究を進めれば, THz-QCLのさらなる動作範囲 の拡大が可能であると考えられる。

\section{参考文献}

1) R. Kohler, A. Tredicucci, F. Beltram, H. E. Beere, E. H. Linfield, A. G. Davies, D. A. Rittchie, R. C. Lotti, and F. Rossi: Nature 417 (2002) 156

2) C. Walther, M.Fiscer, G. Scalari, R. Terazzi, N. Hoyler, and J. Faist: Appl. Phys. Lett. 91 (2007) 131122.

3) C. W. I. Chan, Q. Hu, and J. L. Ren: Appl. Phys. Lett. 101 (2012) 151108.

4) S. Fathololoumi, E. Dupont, C. W .I. chan, Z. R. Wasilewaski, S R. Laframboise, D. Ban, A. Matyas, C. Jirauschek, Q. Hu, and H. C. Liu: Opt. Express 20 (2012) 3866.

5) L. Li, L. Chen, J. Zhu, J. Freeman, P. Dean, A. Valavanis, A. G. Davies and E. H. Linfield: Electron. Lett. 50 (2014) 309.

6) 平山秀樹, 寺嶋亘, 林宗澤 : Optronics 5 (2013) 81 .

7）平山 秀樹：オプトニューズ 9 (2014) 27.

8) T. T. Lin, L. Ying, and H. Hirayama: Appl. Phys. Express 5 (2011) 012101.

9) T. T. Lin and H. Hirayama: Phys. Status Solidi (c) 10 (2013) 1430 .

10) M. Sasaki, T. T. Lin, and H. Hirayama: Phys. Status Solidi (c) 10 (2013) 1448

11) W. Terashima and H. Hirayama: Proc. SPIE 8625 (2013) 861516.

12) W. Terashima and H. Hirayama: Appl. Phys. Express 3 (2010) 125501.

13) W. Terashima and H. Hirayama: Phys. Status Solidi (a) 208 (2011) 1187.

14) M. Yamanishi, K. Fujita, T. Edamura, and H. Kan: Opt. Express 20 (2008) 207408.

15) S. G. Razavipour, E. Dupont, S. Fathololoumi, C. W. I. Chan, M Lindskog,Z. R. Wasilewski, G. Aers, S. R. Laframboise, A. Wacker, Q. Hu, D. Ban, and H. C. Liu: J. Appl. Phys. 113 (2013) 203107.

16) S. G. Razavipour, E. Dupont, C. W. Chan, C. Xu, Z. R. Wasilewski, S. R. Laframboise, Q. Hu, and D. Ban: Appl. Phys. Lett. 104 (2014) 041111

17) S. Kumar, C. W. I. Chan, Q. Hu, and J. L. Reno: Nature Phys. 7 (2012) 166

18) B. S. Williams, S. Kumar, Q. Hu and J. Reno: Electronics Lett. 42 (2006).

19) A. Wacker: Appl. Phys. Lett. 97 (2010) 081105.

20) H. Yasuda, I. Hosako, and K. Hirakawa: CLEO 2012 Technical Digest, JW2A.91, May 2012.

21) H. Yasuda, T. Kubis, I. Hosako and K. Hirakawa: J. Appl. Phys. 111 (2012) 083105. 